\title{
WILLINGNESS TO PAY FOR THE NATIONAL HEALTH INSURANCE PREMIUM AMONG TRADERS IN OGAN HILIR, SOUTH SUMATERA
}

\author{
Anjelina Dwi Yunianti'), Misnaniarti²) \\ 1)Faculty of Public Health, Universitas Sriwijaya \\ 2)Department of Health Policy and Administration, Faculty of Public Health, \\ Universitas Sriwijaya
}

\begin{abstract}
Background: The Indonesian National Health Insurance (NHI), namely Jaminan Kesehatan Nasional (JKN), aims to achieve Universal Health Coverage (UHC). UHC exists when all people receive the quality health services they need without suffering financial hardship. This study aimed to examine willingness to pay (WTP) for NHI premium among traders in Ogan Hilir, South Sumatera.

Subjects and Method: This was a cross-sectional study conducted at Simpang Timbangan Community Health Center, Ogan Hilir, South Sumatera. A total of 106 traders were selected for this study by random sampling. The dependent variable was WTP of NHI premium. The independent variables were age, sex, existing chronic disease, ability to pay, income, information about NHI, perceived completeness of health facility, and distance to health facility. The data were collected by questionnaire and analyzed by a multiple logistic regression.

Results: As much as $55.6 \%$ of the sampled traders were willing to pay for NHI premium. The WTP of NHI premium increased with female $(\mathrm{OR}=1.75 ; \mathrm{p}=0.048)$, older age $(\mathrm{OR}=3.10 ; \mathrm{p}=0.037)$, existing chronic disease $(\mathrm{OR}=5.21 ; \mathrm{p}=0.022)$, high income $(\mathrm{OR}=7.54 ; \mathrm{p}=0.001)$, well informed of NHI $(\mathrm{OR}=4.02 ; \mathrm{p}=0.025)$, and complete facility $(\mathrm{OR}=2.23 ; \mathrm{p}=0.047)$. The WTP of NHI premium decreased with lower education $(\mathrm{OR}=0.52 ; \mathrm{p}=0.048)$, poor knowledge of $\mathrm{NHI}(\mathrm{OR}=0.43$; $\mathrm{p}=0.037)$, large family size $(\mathrm{OR}=0.22 ; \mathrm{p}=0.001)$, and distant to health facility $(\mathrm{OR}=0.60 ; \mathrm{p}=0.025)$.

Conclusion: The WTP of NHI premium increases with female, older age, existing chronic disease, high income, well informed of NHI, and complete facility. It decreases with lower education, poor knowledge of NHI, large family size, and distant to health facility.
\end{abstract}

Keywords: national health insurance, premium, willingness to pay, trader.

\section{Correspondence:}

Misnaniarti. Department of Health Policy and Administration, Faculty of Public Health, Universitas Sriwijaya, Jl. Palembang-Prabumulih KM. 32 Indralaya, Ogan Ilir, South Sumatera 30662. Email: misnaniarti@fkm.unsri.ac.id.

Mobile: 089679666084 